\title{
TEORIAS ÉTICAS COMO PARÂMETRO DA GESTÃO DAS ORGANIZAÇÕES EDUCACIONAIS SUPERIORES
}

\author{
Almiro Schuz \\ Vanda Cunha Albieri Nery
}

\begin{abstract}
RESUMO
O texto tem como preocupação central refletir sobre a relação entre ética e gestão de instituições educacionais. É fruto de preocupações e de pesquisas em desenvolvimento voltadas, principalmente, para o âmbito da gestão. O objetivo principal é mostrar como as várias teorias éticas podem nortear as ações para uma gestão ética. Sua relação e contribuição, como parâmetros para uma gestão ética, estão condicionadas pelos modelos da gestão e pelos pressupostos básicas das teorias éticas, entre elas, a utilitarista tem tido maior aplicabilidade na gestão das organizações.
\end{abstract}

Palavras-chave: Gestão. Ética. Organização.

\begin{abstract}
The central concern of this text is a reflection on the relationship between ethics and the administration of educational institutions. It is the fruit of concerns and research in development directed principally toward the administrative environment. The principal objective is to show how various ethical theories can guide actions toward ethical administration. Their relationship and contribution

Doutor em Educação e Professor e Coordenador do Curso de Mestrado em Educação Superior do Centro Universitário do Triângulo - UNITRI.

** Doutora em Comunicação e Semiótica e Professora e Coordenadora do Curso de Publicidade do Centro Universitário do Triângulo - UNITRI.
\end{abstract}


to parameters for ethical administration are conditioned by the models of administration and by the fundamental presuppositions of the theories. Among the theories, the utilitarian theory has had greater application in the administration of organizations.

Keywords: Administration. Ethics. Organization.

Numa reportagem publicada pela Revista Exame, David Cohen escreve: "poucos assuntos têm sido tão discutidos nas empresas do mundo inteiro quanto a ética corporativa". (2003, p.35). Será um modismo ou é relevância? Cresce o interesse das empresas em promover estudos sobre padrões éticos. Consultores estão se especializando em ética empresarial e centros de estudos de ética voltados para organizações estão surgindo, como é o caso do Centro de Estudos de Ética nas Organizações, da Fundação Getúlio Vargas, de São Paulo. A "pregação ética", bem como o treinamento em comportamento ético empresarial, tem despertado a atenção de muitas instituições, empresas e gestores.

O texto que ora apresentamos tem como preocupação principal refletir sobre a relação entre ética e gestão das instituições e/ou organizações educacionais superiores, fruto de preocupações e de pesquisas em desenvolvimento voltadas, principalmente, para o âmbito da gestão. Constata-se que os termos organização e gestão que, prioritariamente, eram usados mais no contexto das ciências administrativas, no campo da empresa e do mercado, aos poucos vêm sendo assimilados e incorporados na linguagem e nas abordagens da administração da educação escolar, mesmo que ainda sofram resistências por parte de políticos e filósofos da educação. No caso da ética, o termo é de uso remoto, mas, no campo da sua vinculação à gestão e excelência organizacional e empresarial, é de uso mais recente, sobretudo, a partir dos anos 90 e neste início de século. Entretanto, no campo da gestão da educação escolar ou das instituições educacionais, a utilização desse termo é ainda restrita.

O objetivo deste texto é apresentar as várias formulações éticas,

Educ. e Filos., Uberlândia, v. 20, n. 39, p. 219-251, jan./jun. 2006. 
que, no decorrer do tempo, constituíram-se, no que se vem considerando como teorias éticas, apontando as similaridades e as diferenças entre essas, mostrando de que forma elas poderão tornarse parâmetros e proporcionar contribuição para o norte das implicações éticas na gestão da educação escolar superior.

O texto está estruturado em quatro partes. Inicialmente, vamos expor alguns conceitos, sobretudo em torno dos quais existem pontos mais polêmicos, como é o caso da gestão e da organização, incorporados no âmbito da educação, e uma idéia sobre a concepção da ética. A seguir, partindo do conceito de ética, apresentaremos uma síntese das suas várias teorias, pontuando alguns de seus aspectos fundamentais. Numa terceira parte, buscaremos uma aproximação entre ética e gestão, mostrando como as várias teorias podem nortear uma gestão ética. Finalmente, exporemos algumas considerações finais, como síntese desse estudo.

\section{Elucidar concepções: organização, gestão e ética}

O conceito de organização, segundo Hegedüs, preceitua que

[...] o ponto de partida para essa noção, cada vez mais freqüentemente usada nas ciências sociais, é a analogia entre organismos animados e sociedade [...], em sociedades a organização apresenta-se como uma unidade de pessoas e grupos separados pela divisão de trabalho mas também cooperando mutuamente. (1996, p.537).

Nesse sentido, a idéia de organização tem, inicialmente, como paradigma a Biologia. Posteriormente, para a explicação de seu desenvolvimento e dinâmica, passou a contar com a Sociologia e com a Psicologia Social.

A título de informação, lembramos que organização, como organização social, tem uma classificação diversa, mas que, basicamente, encontra sua diferenciação de origem em gemeinschaft, cuja participação é decorrente de uma forma natural, 
por nascer e viver em comunidade; já o termo gesellschaft, organização que se forma por adesão, mais pragmática, utilitária e também em que as relações são mais frágeis.

Segundo Druker (2002, p.59), nas últimas décadas do século $X X$, as várias e diferentes instituições começaram a aplicar conceitos e métodos de administração de empresas, mas o novo é que elas estão tomando consciência de que são "organizações" e, conseqüentemente, a administração pressupõe pontos em comum. Elas podem ser diferentes entre si quanto aos seus objetivos e missão específica mas, na administração, são parecidas. Druker chega a afirmar que vivemos a época das organizações.

Etzioni (1972, p.11) considera que organizações e instituições podem ser entendidas como sinônimo, mas dá preferência ao termo organizações, definindo-as como: "[...] unidades sociais (ou agrupamentos humanos) intencionalmente construídas e reconstruídas, a fim de atingir objetivos específicos" (ETZIONI, 1972, p.9).

Surge, no entanto, uma questão polêmica, sobretudo quando se passa a considerar as instituições educacionais como organizações, se elas podem ou não ser caracterizadas e qualificadas como tais. De acordo com Srour (1998, p.12), confunde-se instituição com organização. Para ele, instituição é um "[...] conjunto de normas sociais, geralmente de caráter jurídico, que gozam de reconhecimento social". (2002, p.12). Nesse sentido, segundo Srour, a instituição apresenta três características básicas: estabilidade estrutural, responsabilidade social e consagração de um complexo de normas; enquanto que organizações "[...] podem ser definidas como coletividades especializadas na produção de um determinado bem ou serviço. Elas combinam agentes sociais e recursos e se convertem em instrumentos da economia de esforço" (SROUR, 2002, p.107).

No âmbito da educação, a filósofa Marilena Chauí, entre outros, critica e é resistente à idéia da qualificação das instituições educacionais como organizações. Segundo ela, essa concepção é resultado da reforma do Estado no período Fernando Henrique Cardoso, que definiu a universidade como uma organização social,

Educ. e Filos., Uberlândia, v. 20, n. 39, p. 219-251, jan./jun. 2006. 
classificando-a como pertencente ao setor de serviços. Chauí considera que:

[...] uma organização difere de uma instituição por definirse por uma prática social determinada por sua instrumentalidade: está referida ao conjunto de meios (administrativos) particulares para obtenção de um objetivo particular [...]. A instituição social aspira à universalidade. Isso significa que a instituição tem a sociedade como seu princípio e sua referência, normativa e valorativa, enquanto a organização tem apenas a si mesma como referência, num processo de competição com outras que fixam os mesmos objetivos particulares. (CHAUÍ, 2003, p.2).

Nessa perspectiva, a organização descaracteriza a educação como um bem público e passa a ser um bem de serviço, de domínio privado. Porém, como contraponto, sob um olhar administrativo, apresentamos as considerações de Costa (1996), segundo o qual, uma organização pode ser entendida como uma dimensão institucional, com traços dominantes. Nesse sentido, ele escreve que "o conceito de escola como organização é de utilidade corrente e pacífica nas áreas da análise organizacional e da administração da educação [...]"(1996, p.10).

O estudo da administração escolar, da estrutura e da dinâmica interna e externa das instituições escolares na perspectiva da Sociologia e, especificamente, da Sociologia Educacional, vem ganhando espaço quando visto à luz das teorias administrativas, dos modelos de gestão, na dimensão do clima e cultura organizacional. Constata-se que, em Portugal, esses estudos e pesquisas têm revelado uma ascensão como ocorre, por exemplo, com Licinio C. Lima que, desde os anos 1980, vem desenvolvendo estudos nesse sentido, cujos resultados são apresentados no seu texto A escola como organização educativa (LIMA, 2001).

Entendemos que essa polêmica, resistência ou aceitação da idéia de que as Instituições de Ensino Superior podem ser consideradas organizações, é profícua, pois, nesse aspecto, vai-se 
lapidando a concepção, tornando-a adequada ao objeto dessas instituições ou organizações, que é a educação, contribuindo para clarear sua especificidade e as possíveis implicações na organização e na gestão, dando-lhe um caráter mais profissional.

Se tomarmos as três características das organizações apresentadas por Etzioni:

1) Divisão de trabalho, poder e responsabilidade de comunicação [...]; 2) a presença de um ou mais centros de poder que controlam os esforços combinados da organização e os dirigem para seus objetivos [...]; 3)substituição do pessoal, isto é, as pessoas pouco satisfatórias podem ser demitidas e designadas outras pessoas para as suas tarefas. (1972, p.10).

Essas e outras características de organizações estão presentes na dinâmica das instituições de educação, por isso, entendemos que elas são organizações.

Não muito diferente, e no mesmo contexto, vem ganhando similaridade o conceito de gestão, cujo uso é bem atual, parece atraente e ocorre em escala múltipla, como por exemplo: gestão de negócios, gestão de recursos humanos, etc. Gestão trata do ato de gerir, vem de gestain, do grego conduzir. Nessa acepção, corresponde à parte técnica, científica, operacional de uma organização ou sistema qualquer.

À primeira vista, gestão é sinônimo de administração. Porém, como vem tomando espaço, a idéia retrata mais a dinâmica de uma instituição ou organização e centra o foco no processo da dinâmica organizacional e num modelo sistêmico e estratégico.

Uma das críticas que se tem levantado, da parte de alguns, ao focar a gestão no processo educacional escolar é que, com essa ênfase, está substituindo-se a preocupação do foco da política educacional por problemas de gestão educacional. Assim, as soluções e os problemas educacionais passam a ser vistos como de gestão, e não de questões políticas. No entanto, uma não suprime a outra: existe a gestão política e a gestão escolar, organizacional.

Educ. e Filos., Uberlândia, v. 20, n. 39, p. 219-251, jan./jun. 2006. 
Contudo, os termos organização e gestão são, cada vez mais, de uso comum, quando se discute a administração da educação escolar.

É também nesse contexto, dos novos enfoques e discursos em torno das organizações e sua gestão, que se verifica o emprego da frase "gestão ética", "ética das organizações". Enfim, a aplicação, a valorização da ética para o campo organizacional e de gestão já é um fato. Diante disso, quer-se, então, esclarecer um pouco sobre o conceito de ética, mesmo considerando que quase todos os textos sobre ética trazem uma explicação sobre a sua concepção.

É com certa freqüência que se ouve o termo ética dando a ela um significado equivocado, muitas vezes, confundindo-o com seu objeto, igualando ética com moral, valores, virtudes, costumes e outros.

Para entender o conceito de ética, podemos partir do significado do termo, do seu emprego e do desenvolvimento da compreensão que se foi elaborando ao longo do tempo. Além disso, é preciso considerar o significado que foi atribuído a ela no campo dos vários saberes, pela Filosofia e Teologia Moral, pelas ciências, como Sociologia e Psicologia.

A palavra ética vem do termo "ethos", cujo significado originário decorre da idéia de habitação, ou morada do homem, seu sistema simbólico, como habitação e, posteriormente, "ethos" também passou a ser entendido como identidade cultural à qual o indivíduo pertence, sua etnia. Lima Vaz, quando discorre sobre o significado do ethos, no texto Ética e Direito, destaca: "É, pois, a partir da própria origem do universo das formas simbólicas que se desdobra a dimensão do ethos: o homem habita o símbolo e é exatamente como métron, como medida do homem" (2002, p.34). Como medida, o ethos pode ser entendido como ponto de partida para o nomos, lei, regra. Assim, ética e moral têm a mesma origem e com significados similares: costumes, caráter, ou seja, retratam uma orientação para o bem, o justo, o feliz. Segundo Freitag, para Platão, "a teoria moral coincide com a busca do bem. Essa busca, por sua vez, encontra sua expressão mais nobre na produção do saber filosófico, no saber que busca a verdade e a justiça" (2002, p.26). 
Com a evolução e a sistematização do pensamento filosófico, a ética passou a ser vista como parte da filosofia e como reflexão sobre a moral. Rios escreve que "[...] verifica-se, entretanto, que ética passa a designar, historicamente, não mais o costume, mas a reflexão sobre o costume, o questionamento do costume, a busca de seu fundamento, dos princípios que a sustentam". (2001, p.101).

Por sua vez, Vazquez estabelece uma distinção entre ética e moral, ponderando que a moral é o objeto da ética, definindo a ética como "ciência da moral".

Também Srour estabelece uma distinção entre ética e moral:

[...] a ética diz respeito à disciplina teórica, ao estudo sistemático, as morais correspondem às representações imaginárias que dizem aos agentes sociais o que se espera deles, quais comportamentos são bem-vindos e quais não. (2002, p.31).

Além das diferenças que Vazquez e outros fazem entre ética e moral, é importante lembrar que a concepção da própria ética pode ser dimensionada como ética filosófica ou ética científica. Nesse sentido, Srour lembra, em relação à ética filosófica ou filosofia moral, que esta: "[...] tende a ter um caráter normativo e de prescrição, ansiosa por estabelecer uma moral universal, cujos princípios eternos deveriam inspirar os homens, malgrado as contingências de lugar e de tempo" (2002, p.39). Em relação à ética científica, ele menciona que essa "[...] tende a ter um caráter descritivo e explicativo porque centra sua atenção no conhecimento das regularidades que os fenômenos morais apresentam, malgrado sua diversidade cultural e apesar da variedade de seus pressupostos normativos [...]" (2002, p.39).

Stoner e Freeman definem a ética

[...] como o estudo do modo pelo qual nossas decisões afetam as outras pessoas. Também é o estudo dos direitos e dos deveres das pessoas, das regras morais que as pessoas aplicam ao tomar decisões, e da natureza das relações entre as pessoas. (1985, p.77).

Educ. e Filos., Uberlândia, v. 20, n. 39, p. 219-251, jan./jun. 2006. 
Percebe-se que a concepção de ética acaba sendo ajustada ao locus de onde se olha e a onde se atua, mas, a idéia de ética como estudo, como teoria, é predominante.

Estabelecidas as noções de ética, quer-se entender como ela pode contribuir para que se efetive uma gestão ética, da educação escolar - Instituições de Ensino Superior. Para que se tenha melhor clareza, é importante que se esclareça como a noção de ética, no decorrer do tempo, foi sistematizando-se, formalizando no que vem a ser chamado de teorias éticas. É o que, então, passaremos a ver.

\section{Teorias éticas}

Inicialmente, podemos afirmar que as teorias éticas que mais influenciaram o pensamento ético ocidental têm, fundamentalmente, duas ou três matrizes e delas desenvolveramse algumas ramificações com focos específicos. Subjazem a essas teorias as concepções de mundo, de homem e de conhecimento. A classificação e a descrição delas dependem do topos, do lugar de onde se fala: da Sociologia, da Filosofia, da Psicologia, das ideologias e da hermenêutica, como se analisam e interpretam, em que bases e paradigmas as posições se firmam. Diante disso, alguns estudiosos usam nomenclaturas diferentes sobre as mesmas teorias, e outros fazem uma classificação diferenciada, atribuindo a elas aspectos diversos.

Ao se falar em teorias éticas, convém esclarecer o que se entende por teoria. Em síntese, teoria consiste numa reflexão sistemática sobre a natureza, estrutura, conteúdos e métodos de estudo sobre um determinado objeto, com base em um paradigma, que resulta num pensamento que adquire penetração, adesão, formando certa escola, com caráter mais permanente. Normalmente, as teorias nascem e desenvolvem-se em momentos e ambientes de contradição e conflito social.

Naturalmente, a questão não é tão simples como aqui posta, pois estão implicadas teoria e prática, seu significado como teoria científica nos vários campos do saber. Tomamos aqui, como teoria, 
a elaboração conceitual, conforme reconhecido e apresentado pelos principais autores sobre a ética.

A título de esclarecimento, nem os estudiosos que refletem sobre a questão ética centram-se nela enquanto seus vários enfoques, muitos deles (as), têm uma preocupação específica, abordam não a ética, mas seu objeto, como ocorre com Piaget, cuja preocupação foi pesquisar como se dá o desenvolvimento da moral e, nessa mesma linha, posteriormente, Kohlberg. Outros centram-se mais nos valores, como foi o caso de Scheller.

Todas as teorias éticas que nasceram e adquiriram esse status, mesmo com suas próprias variáveis, estão assentadas numa concepção relacionada às fundamentações, concepção filosófica, científica do real. O real é entendido como aquilo que é existente, primeiro e último, no vir a ser, ou na sua ausência, o nada, baseado no que se entendia por natureza, da vida e do conhecimento, em contextos conflituosos.

Assim, no mundo clássico grego, a ética surge num embate entre uma concepção relativista e metafísica, objetiva. O contexto das primeiras formulações em torno da ética ocidental nasce da crítica , da anarquia, da reação sofista diante do status quo, baseado na negação do conhecimento objetivo e na transitoriedade. Portanto, uma ética relativista. Como reação, Sócrates, Platão e Aristóteles representam o contraponto que, apesar das suas diferenças entre si, apresentam uma outra concepção do real. Platão, na perspectiva idealista, e Aristóteles, na visão real naturalista. Com base nessas concepções e na dinâmica social de seu tempo, construiu-se suas contribuições éticas.

Por sua vez, os estóicos e os epicureus, que centraram suas preocupações principalmente na questão ética, afirmando o primado da questão moral (SBBAGNAND, 2000, p.375), tomaram como base o cosmos, a natureza, dando a ética um status objetivo. Para os epicureus, o prazer é o objetivo natural e moral (CORTINA, 2003, p.24). Morais lembra que "[...] a moral de Epicuro busca na consciência adequada da ordem cósmica o fundamento da conduta mais propícia à felicidade". (1998, p.63) . Tem-se como paradigma, prioritariamente a Física.

Educ. e Filos., Uberlândia, v. 20, n. 39, p. 219-251, jan./jun. 2006. 
Com o nascimento e desenvolvimento do cristianismo, a concepção da ética passou a ser vista a partir do fundamento religioso, como síntese da ética hebraica e das concepções helenistas. As duas concepções do mundo clássico grego que marcaram o Ocidente passaram a realizar isso pelo cristianismo, o platonismo, pelo pensamento de Agostinho e o aristotelismo, por intermédio de Tomas de Aquino. Nesse período, desde Platão e Aristóteles até a modernidade, a ética foi vista sobre bases transcendentes e da natureza.

No contexto da gestão e do nascimento do pensamento moderno, as visões passaram por metamorfoses em que as bases sobre as quais se fundamentava a ética: religiosa, natureza, foram sendo substituídas pelo fundamento antropológico, pela razão. Assim, a ética e a questão da moral passaram a ser analisadas com base no sujeito, ou pela sua experiência (empírico) ou pela sua razão (racionalidade).

O marco dessa mudança é atribuído a Kant, tornando-se, assim, o referencial, mas que, em seus estudos e análise sobre a questão moral, procurou ainda fundamentá-la sob categorias a priori, universais. Cortina lembra escrevendo que:

[...] no final do século 18, Immanuel Kant muda o rumo no que se refere ao modo de entender o saber moral. Afirma que é evidente que todos os seres vivos, por natureza, tendem ao prazer, e que todos nós, seres humanos, por natureza não podemos ser morais, já que não podemos escolhê-los. A natureza é o reino da necessidade, e não da liberdade, por mais que possamos escolher os meios. Por isso, são fins morais aqueles que podemos propor livremente a nós mesmos, e não os que já nos vêm impostos pela natureza. (2003, p.25).

A questão ética, a moral, então, tem como pressupostos a liberdade, a autonomia. Kant centra a questão no sujeito. Seu pensamento sobre a moral foi apresentado, pela primeira vez, na sua obra Fundamentos da metafísica e dos costumes. É preciso considerar que Kant desenvolveu seu pensamento sobre a moral, 
a ética, a partir do pensamento dos jusnaturalistas, contratualistas, que discutiram as questões em torno dos direitos naturais do homem, sobretudo a questão da liberdade, a propriedade e justiça, baseadas na razão, pelo consenso e estabelecimento de um contrato, principalmente a partir de Hobbes, Locke, Hume e Rousseau.

Segundo Hobbes, como mostra Lopes de Sá, o básico na conduta é a "conservação de si mesmo", seu bem maior. Defendese os direitos naturais, como a liberdade e a justiça (LOPES DE SÁ, 2001, p.31), Porém, só podem ser garantidos por um poder acima das partes, atribuído em consenso por elas, que é o Estado.

Kant dialogou, sobretudo, com o pensamento de Rousseau, que se centrou, fundamentalmente, em duas leis que julgara natural: a da natureza e a da sociedade, sendo que a primeira é abordada nos seus textos Emílio e a segunda, no texto O contrato social. Freitag informa que "No Emílio, Rousseau discute o desenvolvimento e a educação necessários da consciência moral de um cidadão ideal; em $\mathrm{O}$ contrato social, discute a construção de um corpo político (república) ideal, como habitat saudável para o seu Emílio" (2002, p.34). Considera, pois, que a moral é um princípio inato e que a pessoa deve governar-se pela própria razão, potencial a ser desenvolvido. Freitag chega a dizer que os escritos de Kant, Fundamentação da metafísica dos costumes e a Crítica da razão pura, foram inspirados em Rousseau e que "As idéias que nortearam Kant quando refletiu sobre a razão prática foram, em sua essência, extraídas do Emílio" (2002, p.45).

Com a evolução, separação e secularização das ciências, os fundamentos no campo da ética passaram a ser vistas como coisa do passado, e o relativismo ético se expandiu, nascendo o niilismo, com a ênfase na finitude, cujo representante por excelência foi Nietzsche, negando qualquer fundamento da ética.

Marchionni relata que o discurso ético é como "casa sem fundações":

Nos últimos anos, a ética virou uma Fênes Árabe, ave lendária que nascia de suas cinzas: dela todos falam, todos a desejam, mas ninguém sabe onde está e como é. A verticosa erupção

Educ. e Filos., Uberlândia, v. 20, n. 39, p. 219-251, jan./jun. 2006. 
de debates, livros e campanhas sobre ética neste limar do Terceiro Milênio, simplesmente denuncia uma perda: algumas comunidades dos homens não mais possuem uma regra de ação. (In: Ética na virada do milênio,1999, p.33).

Percebe-se que os clássicos e medievais tinham, em seu método de discurso, a questão do que "a coisa é", seu ser, seu fundamento, enquanto na modernidade e contemporaneidade, a questão é mais centrada no "como", no funcionamento "da coisa". Parece até que falar da essência, da ontologia é coisa do passado, e os que discutem, em suas teorias éticas, a superação do relativismo ético, mesmo assim, parecem não querer comprometer-se em afirmações que se reportam aos fundamentos da natureza, do religioso ou similares.

Postos alguns aspectos em torno dos vários fundamentos éticos, iremos, então, relacionar as teorias e suas implicações para a gestão ética da educação escolar- Instituições de Ensino Superior.

Inicialmente, tomamos aqui as três matrizes básicas da formulação das teorias éticas ocidentais e, depois, mostraremos os seus desdobramentos. Essa opção pode parecer simplista, mas o nosso objetivo, ao adotá-la, é facilitar o entendimento das idéias que estamos desenvolvendo. Não se trata aqui de "coisa" inédita, pois a classificação já é feita e há, como já dito anteriormente, diferenciações em sua classificação e nomenclatura.

Uma das matrizes sob a qual se desenvolveu uma teoria ética, e com ramificações posteriores, é a ética de Aristóteles.

A teoria ética com base em Aristóteles é chamada de "Ética das Virtudes", "Ética Teleológica" ou "Ética Finalista". É assim chamada porque focaliza a questão ética no bem, no resultado das ações, como um fim a ser alcançado por meio da conduta do homem, e não por meio da observação de preceitos. Sua idéia está ligada a telos, que, em grego, significa fim, finalidade, propósito, tendência ou direção para uma meta - e a virtudes, porque sua concepção de ética realiza-se com base no desenvolvimento das virtudes, nos hábitos.

Tugendhat, no seu texto Lições sobre ética (1996), dedica alguns capítulos ao estudo da ética de Aristóteles e ele a identifica como a 
"ética das virtudes". Pegoraro, no seu texto Ética e Justiça (1995), divide o seu estudo da ética em duas matrizes principais: "ética das virtudes" e "ética das normas". A primeira, a que está neste momento sendo considerada, conceitua: "A ética aristotélica propõe a superação do conflito pela prática das virtudes orais que, aos poucos, subordinam a paixão à razão. Quando isso acontece, o homem torna-se senhor de si mesmo" (1995, p.12).

Aristóteles traça o ideal moral do homem livre e culto, de cidadão. Por isso, faz-se a ele a crítica de que sua ética é classista, com base no conceito de felicidade (eudaimonia) em relação ao qual se joga toda a dimensão ética do homem. O homem, como ser ético, tende para um fim, que é o bom, que se realiza na busca e conquista por meio das virtudes morais e intelectuais (dianoéticas). Entretanto, isso não ocorre no privado, entendido como espaço da relação familiar, o oikos, mas na polis, no coletivo, na dimensão pública. Isso fica claro no seu texto sobre a política. Nele, Aristóteles expõe as idéias do homem como um ser por natureza político e, assim, o telos, a felicidade, o bem conquistam-se de uma forma contínua na dimensão do exercício da cidadania.

A felicidade é o fim natural de nossa vida, mas, é também o fim moral, pois a felicidade não é um dado, mas uma conquista. Como resalta Cortina, "alcançá-la ou não depende de sabermos escolher os meios mais adequados para chegar a ela, e de agirmos de acordo com a escolha feita". (2003, p.23). A ética das virtudes de Aristóteles está intimamente associada à educação, à formação, à paidéia grega. Não quer dizer que não haja lugar ou que se exclua o estabelecimento de normas. Porém, não se constitui um fim em si, mas um meio para um fim, que é o norte da conduta, da moral.

Hoje, algumas teorias são desdobradas em maior ou menor grau da matriz aristotélica, conhecidas por "Ética das Conseqüências". O ressurgimento das tendências aristotélicas, também chamadas de tendências "neo-aristotélicas", começou, sobretudo, após a Segunda Guerra Mundial, focando aspectos diversos. Alguns dos autores centram suas reflexões com base na noção aristotélica da práxis, sua revalorização, como é o caso de Arfent (OLIVEIRA, 2001, p.14) outros na phronesis, entendida

Educ. e Filos., Uberlândia, v. 20, n. 39, p. 219-251, jan./jun. 2006. 
como "o conhecimento moral que implica deliberação e aplicação a uma situação concreta" (OLIVEIRA, 2001, p.10), como é o caso de Gadamer, outros na arete - virtudes - como é o caso de Maclntyure (OLIVEIRA, 2001, p. 20).

Uma segunda matriz pode ser encontrada na ética de Epicuro. Segundo essa concepção ética, "age moralmente quem sabe calcular de forma inteligente, na hora de tomar decisões, as opções que proporcionarão conseqüências mais prazerosas e menos dolorosas, e escolhe em sua vida as que produzem mais prazer e menos dor" (CORTINA, 2003, p.24). É chamada de ética do prazer, ou ética hedonista. Hedonista vem do termo grego hedomé, que significa prazer. Para essa concepção, o pressuposto básico é que o prazer é o bem supremo. Morais explica: "Seu ponto de partida, com efeito, é a constatação de que o prazer é a concretização do que é bom para nós, e a dor, do que é mau". (1998, p.68).

É preciso considerar que existem incontáveis fontes, situações que geram prazer e dor, e elas mesclam-se no cotidiano. Diante disso, o papel da ética, ou seja, a sabedoria ética é que permite que façamos escolhas e busquemos os prazeres mais consistentes. A idéia não é que qualquer prazer é bom. "Epicuro estava supondo que viver é um bem e que, portanto, para ser boa, basta que a vida não seja demasiado perturbada por dor e sofrimentos" (MORAIS, 1998, p.69). Num texto, transcrito por Cabanas, Epicuro faz as seguintes considerações:

Quando décimos que el placer es la finalidad única, no estamos aludiendo a los placeres de los disolutos e de los crápulas, como piensan algunos que desconecen nuestra doctrina e no están de acuerdo com ella o la intrerpretan mal. Pues ni los banquestes ni lãs fiestas continuas, ni el gozar de mancebos y mujeres, ni el pescado ni otros alimentos que oferecen lãs mesas abundantes nos hacen agradable la vida, sino el juicio acertado que examina las causas de cada acto de aceptación o derechazo y sabe guiar nuestras opiniones lejos de aquellas que llenan el alma de inquietud. De esto es principio el buen juicio. (apud, CABANAS, 1995, p.114). 
De acordo com essas suas observações, o ideal do prazer só é possível para o sábio, que é capaz de discernir entre o que proporciona mais prazer. Diferente de Aristóteles, que entendia que a felicidade se realizaria na polis, Epicuro propõe a "vida no jardim", local onde vivia com seus amigos. Morais lembra ainda que "tal é o objetivo da ética epicúria: ensinar-nos a cuidar de nossa vida como de um belo jardim. Justamente por constituir o bem fundamental de que dispomos, a vida merece os melhores cuidados" (1998, p.12)

Segundo Cortina, a ética do prazer (hedonista) está presente na versão ética utilitarista. "[...] o hedonismo moderno (utilitarista) propõe como meta moral atingir a maior felicidade (o maior prazer) para o maior número possível de seres vivos. (2003, p.25). Também Oliveira, no texto Correntes fundamentais da ética contemporânea, mostra as várias concepções ou vertentes do hedonismo, hoje denominado de utilitarismo. Ele escreve que:

[...] Poderíamos escolher os seguintes aspectos como sendo os que melhor caracterizam a estirpe utilitarista: a idéia de que a ética não é indiferente ao bem-estar das pessoas, que a qualidade moral de nossas ações/regras, é função de suas conseqüências, que o bem dos indivíduos afetáveis por um curso de ação deve ser maximizado e seu sofrimento minimizado, e que a ética deve se importar não apenas com o bemestar ou sofrimento do agente moral, mas com a qualidade de vida de todos os seres capazes de sentir e de sofrer, potencialmente atingidos por um curso de ação. (2000, p. 100).

Também Cabanas (1995), no texto Pedagogia moral: el desarrolo moral integral, ressalta que o mundo ocidental está marcado pelo hedonismo, que o progresso econômico e a elevação do nível de vida indicam a felicidade como filosofia de vida, mostrando sua presença em algumas concepções da sociologia sobre a moral. $\mathrm{O}$ juízo moral está baseado na utilidade, no resultado funcional.

Para ampliar as nossas considerações sobre as matrizes e teorias éticas, Srour (2003), ao comentar as diferentes teorias, no

Educ. e Filos., Uberlândia, v. 20, n. 39, p. 219-251, jan./jun. 2006. 
texto Ética empresarial, toma como base a classificação feita por Max Weber. No capítulo sobre as teorias éticas, ele as vincula a duas matrizes principais: "Ética da Convicção" e "Ética da Responsabilidade". Abordaremos a "Ética da Convicção" mais adiante, pois é a "Ética da Responsabilidade" que, de acordo com sua classificação, aproxima-se da teoria agora em questão.

De acordo com a síntese apresentada no seu texto, Srour afirma que a "Ética da Responsabilidade" consiste no seguinte:

É uma ética dos propósitos, da razão, dos resultados previsíveis, dos prognósticos, das análises de circunstâncias dos fatores condicionantes. Enfrenta a vertigem das perguntas e do desafio das soluções relativistas. Corresponde a um relativismo pragmático - analítico, calculista, indutivo, pluralista, flexível. Ética situacional e condicional, moldada pelo ceticismo e pelas análises de risco (SROUR, 2003, p.140-141).

Anterior a essa síntese, Srour explica:

[...] a máxima da ética da responsabilidade, por sua vez, apregoa que somos responsáveis por aquilo que fazemos. Em vez de aplicar ordenamentos previamente estabelecidos, os agentes realizam uma análise situacional: avaliam os efeitos previsíveis que uma ação produz; planejam obter resultados positivos para a coletividade; e ampliam o leque das escolhas ao preconizar que dos males o menor ou ao visar fazer mais bem ao maior número possível de pessoas (2003, p.110).

Com essas observações sobre a "Ética da Responsabilidade", é possível estabelecer uma relação tanto com a matriz aristotélica, bem como com a matriz epicureu, mas, sobretudo, com a versão utilitarista. O próprio Srour subdivide a "Ética da Responsabilidade" em duas vertentes: "a utilitarista" e a que chama de "a da finalidade".

Segundo o utilitarismo, como visto, a ética requer que as ações sejam conduzidas para que seu resultado seja o máximo bem para o 
maior número de pessoas. Lembrando que, no seu interior, alguns o classificam em utilitarismo egoísta e altruísta, ou seja, que pode ter um norte egoísta ou altruísta, sendo que o egoísmo somente leva em conta as conseqüências sobre o próprio indivíduo, enquanto o coletivismo ou altruísmo considera sobre as demais pessoas, ou se preocupa em extender benefícios ao maior número possível de pessoas.

Segundo Holmes (2002, p.47), o utilitarismo "[...] foi a abordagem ética que mais influenciou, no século $X X$, a filosofia dos países de língua inglesa".

Sobre a outra subdivisão que Srour faz da ética da responsabilidade, "a da finalidade", declara que "a bondade dos fins justifica as ações empreendidas, desde que coincida com o interesse coletivo, e supõe que todas as medidas necessárias sejam tomadas [...]" (2002, p.114).

Essas tendências éticas desenvolveram-se mais onde o empirismo e o pragmatismo tiveram maior influência, também representam uma aproximação maior com os interesses econômicos e do mercado.

Tanto a teoria aristotélica - a ética das virtudes - como a epicurista - a ética do prazer -, e seus vários desdobramentos ou vertentes contemporâneas convergem para uma ética teleológica, finalista.

Uma terceira matriz, que pode ser atribuída à concepção ética de Kant, tornou-se o referencial e marco para determinado segmento de concepções éticas. Pegoraro observa que:

Kant é verdadeiramente um marco central da história da ética: por um lado representa o ponto de chegada de um movimento que remonta ao fim da Idade Média, segundo o qual a ética consiste num equilíbrio entre lei e liberdade; por outro, ele é o lugar de referência da reflexão ética posterior. (1995, p.54).

O movimento, como "ponto de chegada", pode ser demarcado desde Occam, com a rejeição da visão universalista, da metafísica grego-medieval. Lutero opôs-se à ética aristotélica, rejeitou seu ensino e aplicação nas universidades que estavam sob sua

Educ. e Filos., Uberlândia, v. 20, n. 39, p. 219-251, jan./jun. 2006. 
influência, com base no argumento segundo o qual a doutrina das virtudes estava em conflito com a doutrina da graça, pois as virtudes atribuem mérito ao homem, enquanto, na concepção da graça, o homem por si é incapaz. No movimento do jus naturalismo, os contratualistas, em torno das discussões sobre o direito natural do homem, desde Hobbes e Rousseau, fizeram surgir uma nova visão sobre o homem e a questão ética, que vai encontrar, na formulação do pressuposto de Kant, a base para uma ética normativista, deontológica.

Segundo a visão kantiana, o dever é o fim em si mesmo: "o dever pelo dever". A razão fornece leis para nosso comportamento

[...] essas leis ordenam incondicionalmente e não prometem a felicidade em troca do seu conjunto, prometem apenas realizar a própria humanidade. Assim sendo, expressam-se como ordens (imperativo) categóricas, incondicionais. Ser pessoa é valioso por si mesmo, e a meta da moral consiste em querer sê-lo acima de qualquer outra meta: querer ter boa vontade para cumprir nossas próprias leis (CORTINA, 2003, p.26).

A ética kantiana e suas manifestações são denominadas por "Ética das Normas", conforme faz Pegoraro (1995); "Ética da Convicção", assim classificada por Max Weber e retratada por Srour (2002), ou, ainda, por "Ética Deontológica".

Srour salienta que "[...] há pelo menos duas teorias éticas, como ensina magistralmente Max Weber: 1. A ética da convicção, entendida como deontológica (tratado dos deveres) [...]" (2003, p.107); 2. "Ética da Responsabilidade", conforme já apresentado anteriormente neste texto.

Em sua exposição sobre a "Ética da Convicção", identifica duas vertentes que denomina como: a de "princípio" e a da "esperança".

1. A de princípio, que se atém rigorosamente às normas morais estabelecidas, em um deliberado desinteresse pelas 
circunstâncias, e cuja máxima sentencia: respeite as regras, haja o que houver;

2. A da esperança, que ancora em ideais, moldada por uma fé capaz de mover montanhas, pois convicta de que todas as coisas podem melhorar, e cuja máxima preconiza: o sonho antes de tudo (2003.p.108).

Convém lembrar que, para Kant, uma vez formalizado e objetivado um código de leis, de normas, e se esse nortear as atitudes, já não se está mais no campo da moral, pois o controle já vem de fora do sujeito.

Da matriz kantiana, ética normativa, deontológica, desenvolveram-se, posteriormente, várias ramificações éticas, chamadas também de cognitivistas, com bases iluministas, abordadas sob as perspectivas da Sociologia (Durkheim, Weber), da Psicologia e genética (Piaget, Kohlberg). Houve também a tentativa e uma aproximação ou superação das matrizes divergentes, como foi o caso de Rawls, que procurou fazer isso por meio da sua teoria da justiça.

Como temos um espaço delimitado para o texto, não nos propomos entrar numa abordagem de todas as variantes. Contudo, dentre elas, a chamada "Ética Dialógica", conhecida também por "Ética do Discurso", ou, ainda, por "Ética Comunicativa", merece um pouco de atenção. Um dos seus representantes de destaque é Jürger Habermas. Basicamente, defende que a razão moral é uma "razão prática dialógica: uma racionalidade comunicativa" (CORTINA, 2003, p.27). Por conseguinte, a decisão não é do indivíduo, mas decorre de uma decisão por aqueles que são afetados pelas decisões, "depois de haver estabelecido um diálogo em condições de racionalidade" (CORTINA, 2003, p.27).

Nesse sentido, a decisão sobre uma norma, se ela é ou não uma lei moral ou se está correta, não é individual, mas coletiva, estabelecida por convenção por meio do diálogo, pela "razão prática dialógica" e não monológica.

Tendo apresentado as principais teorias éticas com seus enfoques básicos, passaremos a algumas considerações no sentido de buscar uma aproximação entre elas e a gestão organizacional.

Educ. e Filos., Uberlândia, v. 20, n. 39, p. 219-251, jan./jun. 2006. 
Lembramos que outra matriz ética que influenciou o pensamento ético ocidental foi a hebraica, mediante a formação do cristianismo. Também, o estoicismo poderia ser visto como matriz, sobretudo, pela influência exercida sobre o pensamento ético do mundo romano. Deixamos de abordá-las por opção, em decorrência da extensão do texto e também porque ambas têm uma aproximação com a ética normativa.

\section{Implicações e parâmetros éticos no processo de gestão}

Abordar a questão das contribuições e dos parâmetros éticos, no processo de gestão e, em especial, nas organizações educacionais, é muito amplo e complexo. Como já relatamos no início, o assunto vem sendo discutido nos últimos anos e tem conquistado espaço e conseguido certo consenso sobre sua pertinência e relevância no âmbito institucional. Mas, tratando-se da gestão ética nas organizações educacionais, é preciso considerar que essas são bem mais abrangentes do que qualquer outra, sob o ponto de vista de sua missão, da sua finalidade, tanto em suas relações internas como nas externas. O resultado das ações de uma organização educacional, seu produto, não é uma simples mercadoria. Nela e dela, cliente e produto se confundem, o resultado esperado não é apenas a informação, a instrumentalização, mas a formação, a cultura.

Se tomarmos como base a concepção que o Governo Federal atual apresenta, nas cinco razões para a reforma da educação superior, o ensino não é mercadoria, mas visto como um bem público, como um direito e, diante disso, a reforma deverá contribuir para que haja controle e venha a impedir a mercantilização da educação superior (www.mec.gov.br/reforma/cinco.asp.passim).

Na gestão organizacional educacional superior, também há implicações que decorrem da variável entre a gestão administrativa, de um lado, e a gestão acadêmica, de outro. Mesmo que não possam ser separadas, não são estanques, mas são dois lados de uma mesma moeda que, juntos, compõem a gestão organizacional educacional. Mas não se pode ignorar que essas 
duas dimensões acabam gerando situações de conflito entre o que vem a ser o fim e o meio.

Outro aspecto ou variável é a própria configuração da estrutura jurídica: públicas e privadas, que passa a contribuir para determinadas situações no processo da gestão, como também a configuração acadêmica, quando as exigências são diferentes entre os vários níveis institucionais, como universidades, centros universitários, faculdades isoladas, etc.

Ao se discutir, então, a gestão ética nas organizações, há uma série de questões que podem ser colocadas, entre elas: se cabe a atribuição, a imputação de responsabilidade ética a uma organização, na condição de pessoa jurídica?

Em relação a essa questão, há divergências. Leisinger e Schmitt (2001, p.24) explicam que a idéia de que pessoas jurídicas (empresas) possuem direitos e deveres morais ganhou consenso. Entre outros argumentos, destacamos sua referência de que " para uma empresa valem as mesmas metas primárias que para as pessoas individuais: a de sua existência, a de sua liberdade de ação e a de sua solidariedade, entendida no sentido de cooperação" (2001. p.22), o que implica, pois, em uma ética organizacional. Por outro lado, há quem discorde, alegando que só o ser humano pode ser entendido como quem age ou não eticamente.

O fato é que não existe uma gestão automatizada e, se essa vier a existir, será programada pelo ser humano. Mesmo que uma instituição ou organização, como pessoa jurídica, adquira um status objetivo, são seus responsáveis que respondem por ela, o que não significa destituí-la de implicações éticas, o que seria esvaziá-la de sentido, de valor, neutralizá-la. Enquanto numa organização define-se missão, finalidade, atribui-se responsabilidade, ocorrem decisões e atribuições, ela está agindo, ou nela se está agindo, com implicações éticas.

Uma outra questão que se coloca é: quais os fatores ou quais variáveis interferem no processo de uma gestão para que se possa cobrar sua ética? Para tanto, podemos relacionar: a estrutura organizacional, o modelo de gestão adotado, a cultura organizacional, social, menor e maior, além, naturalmente, dos

Educ. e Filos., Uberlândia, v. 20, n. 39, p. 219-251, jan./jun. 2006. 
sujeitos envolvidos mediante suas ações. Se há essas variáveis, em que medida elas exercem um condicionamento sobre o nível da gestão ética? Não significa, necessariamente, que os gestores são suprimidos como sujeitos, mas, uma vez cristalizada uma estrutura e determinada cultura de uma organização, e adotado determinado modelo de gestão, esses e outros exercerão influência sobre os gestores, e influenciarão no padrão ético organizacional. Brien, consultor de ética empresarial, comenta que se perguntava "por que as pessoas boas fazem coisas ruins"? E qual é o papel da cultura organizacional dentro do ambiente de trabalho? (www.eticaempresarial.com.br/entrevista_jerry.html).

Para aproximar de como as várias concepções éticas podem iluminar as ações de gestão, para que sejam éticas, lembramos que, se há clareza sobre o modelo de gestão que uma determinada organização adota, poder-se-á, com mais facilidade, verificar qual das teorias éticas que melhor se ajusta e pode nortear o desenvolvimento de sua prática. É verdade que, ao se fazer essa observação, surge a pergunta: o modelo de gestão condiciona a forma de gestão ética, ou uma teoria ética deverá e poderá contribuir para a configuração de um modelo de gestão? Como se percebe, estamos levantando questões que não têm respostas simples e não é nosso objetivo discuti-las, mas dizer que se tem conhecimento de que essas questões existem.

Se o modelo de gestão for autoritário, centralizador e burocrático, das várias abordagens éticas ou teorias, a que melhor se ajusta é a ética normativa, ou seja, a do âmbito deontológico. Pois um sistema burocrático requer normatizações, um sistema centralizador requer que haja padronização das ações, ajustadas ao mando centralizado. Nesse caso, é importante que a instituição ou organização elabore e deixe claras as suas normas de procedimentos por meio de seu regimento; seus valores institucionais, mediante um código "ético," elaborado especificamente, e que haja clareza e que seja de conhecimento dos gestores de todos os níveis. Com isso, não estamos afirmando que a ética normativa não se aplica a outros modelos de gestão.

Leisinger e Schmitt (2001, p.124), no texto Ética empresarial: 
responsabilidade global e gerenciamento moderno, lembram que a implementação de normas éticas numa instituição serve de orientação nas situações eticamente confusas. A implementação de uma prática ética, com base num sistema de normas, não é tão simples. Se é elaborada e decretada de cima para baixo, poderá não haver um comprometimento e, se for dentro de um processo democrático, dialógico, o desgaste será maior, uma vez que estará em jogo a variedade de posições. Contudo, a médio e longo prazo, trará maior resultado. Leisinger e Schmitt (2001, p.124) sugerem que, havendo normas éticas da organização, essas devem ser anunciadas e, para que se tornem claras, é importante que se adote um programa de comunicação que propicie possibilidade de espaço onde dúvidas possam ser esclarecidas, no qual não se dê apenas a informação, o que, muitas vezes, só é feito de forma impressa.

É importante considerar que tomar os valores organizacionais como referência da gestão ética contribuirá para que possíveis dilemas morais sejam evitados. Porém, isso não é simples, pois sabese que se está diante de uma questão sobre a qual há muitas divergências e, para entrar nesse mérito, tornar-se-ia necessário considerar as diferenças de correntes das várias situações históricas e cosmovisões, construídas sobre paradigmas e teorias subjacentes. Existem várias concepções sobre o que são valores, sobre suas fontes, função e classificação.

Com isso, não se está desconsiderando sua pertinência e viabilidade de uso, muito pelo contrário: os valores merecem, oportunamente, um estudo e um tratamento em especial. Nesse momento, apenas lembramos que eles exercem um papel significativo, sobretudo quando a organização tem clareza sobre quais são os seus valores, os deixa claros, definidos e os pratica. Eles constituem-se como guia, tanto para as ações como para as decisões, e exercem um impacto sobre a formação do comportamento dos sujeitos da organização (TAMAYO, s/d, p. 183). No entanto, é importante lembrar que nem todos os valores que uma organização estabelece como seus são necessariamente éticos. Segundo Tamayo, "os valores organizacionais são crenças sobre o que é bom e desejável para a empresa" (s/d, p.175). Poderá

Educ. e Filos., Uberlândia, v. 20, n. 39, p. 219-251, jan./jun. 2006. 
haver conflito com o que é bom e justo à luz dos valores morais fundamentais, como também, pode haver choque entre os valores do indivíduo e os da organização, que deve ser evitado. Tamayo lembra que "os valores organizacionais não devem ser confundidos com os valores pessoais dos membros da organização, nem com os valores que eles gostariam que existissem na empresa" (s/d, p.189).

À luz da concepção kantiana, tanto para a elaboração de códigos normativos, como para um agir ético em geral, convém considerar que a ética normativa não se aplica, ou ela não contribui, só por meio da elaboração de um sistema de normas da instituição, mas também se aplica para quaisquer ações e decisões. Segundo Kant, não se deve tomar como base a experiência empírica, pois essa só revela "o que é e não o que deve ser". Fatos empíricos fornecem somente dados, mas não deveres. Nesse sentido, a única base para a ética é categórica. É preciso, então, partir do "imperativo categórico".

Kant apresenta o imperativo categórico por intermédio de várias formas, como:

Aja somente de acordo com aquela máxima pela qual você possa, ao mesmo tempo, desejar que se torne uma Lei universal, [...] aja como se a máxima da sua ação fosse, mediante a sua vontade, tornando-se uma lei universal da natureza, [...] aja de tal maneira que trate a humanidade, seja na sua pessoa, seja na pessoa dalgum outro, sempre como fim e nunca como apenas um meio. (apud, GEISLER, 1972, p.74).

Com base nas suas máximas, o agir ético não deve basear-se ou justificar-se em resultados utilitaristas, bem como deve se evitar o que é contrário à razão; é por meio dela que se chega ao que é intrinsecamente certo.

As várias vertentes da ética deontológica ou normativa propõem que as organizações e gestores ajam com base em princípios ou normas pré-estabelecidas, por convenção, pelo consenso ou por meio de uma argumentação dialógica, como é o caso da ética do discurso, anteriormente identificada, segundo a 
qual, a norma se estabelece e tem sua validade a partir do "consenso dos que argumentam". Nesse caso, o certo não é estabelecido pelos que têm mais poder na organização e de forma individual, mas resultado da participação de todos.

Além das éticas normativas ajustarem-se melhor a um modelo de gestão centralizado, considerando que a instituição possuiu seus valores de forma clara e seus procedimentos normatizados, fica mais fácil para o gestor ajustar suas ações e decisões com base nesses valores e procedimentos. Convém, entretanto, ponderar que se pode configurar um sistema, uma "camisa de força" legalista e que é muito difícil um sistema de normas atender a todas as situações - as imprevisíveis e os vários dilemas que surgem. É difícil, portanto, quando as situações estão encobertas pela ambigüidade ou pela falta de informação suficiente. Contudo, dentro dessa perspectiva, é possível uma gestão ética convencional, conforme define Kohlberg (BIAGGIO, 2002), como o terceiro estágio da evolução da consciência moral. Significa respeito às leis e à ordem.

É o nível em que se há respeito pela autoridade, pelas regras fixadas. Ser ético é cumprir o dever, as normas estabelecidas não são questionadas. Segundo a pesquisa de Kohlberg, é o nível mais freqüente (BIAGGIO, 2002, p.26). Cabanas informa que, nesse estágio, "considera-se o sistema social por cima dos desígnios individuais" (1995, p.431) . Para alguns, como Cabanas, a ética da convicção é uma ética do nível médio .

Se o modelo de gestão for participativo, descentralizado e flexível, a teoria teleológica, sobretudo na vertente utilitarista, é a que melhor se ajusta. Além do mais, atende e está mais adequada à dinâmica interna e externa de uma organização, em especial, de uma empresa. Lembramos que seu princípio básico é o alcance do bem maior para a maioria, e que as normas não têm um fim em si . Isso não significa a eliminação de normas ou códigos, mas além de serem explícitos para serem úteis, devem permitir espaço para que os gestores julguem situações. Isso requer, então, maior responsabilidade dos gestores para tomar decisões éticas e, diante disso, maior formação ética, ficando um peso maior sobre a conduta ética dos indivíduos.

Educ. e Filos., Uberlândia, v. 20, n. 39, p. 219-251, jan./jun. 2006. 


\section{Andrews escreve que}

[...] As decisões éticas impõem três qualidades individuais, a serem admitidas e desenvolvidas. A primeira é competência para identificar questões éticas e para considerar os efeitos de resoluções alternativas. A segunda é autoconfiança para buscar diferentes pontos de vista e depois decidir o que é certo em determinadas circunstâncias de tempo, de lugar, assim como num dado conjunto de relacionamentos e condições. A terceira é o que William James chamou de oponiaticidade firme (toughmindness), que, em gestão, é a disposição para tomar decisões quando não se sabe tudo quanto se precisa saber e quando as questões que exigem respostas não têm soluções definitivas e incontroversas (HARVARD BUSINESS REVIEW, 2005, p.65).

Só é possível, de um lado, tal perspectiva de gestão ética, onde o modelo de gestão seja descentralizado, onde haja delegação de autoridade, onde se exija confiança e também tolerância em relação a possíveis erros. Do outro lado, requer-se dos gestores competência, não só técnica, mas ética. Como visto, exige-se que os gestores tenham maior capacidade e formação ética. Não basta apenas um nível de conhecimento ético convencional, se tomarmos como base Kohlberg, mas um estágio ético que se denomina pós-convencional, estágio em que, segundo Biaggio:

As leis não são mais consideradas válidas pelo mero fato de serem leis. O indivíduo admite que as leis ou costumes morais podem ser injustos e devem ser mudados. A mudança é buscada por meio dos canais legais e dos contratos democráticos [...] e, se as leis injustas não puderem ser modificadas pelos canais democráticos legais, o indivíduo ainda assim resiste às leis injustas (BIAGGIO, 2002, p.27).

Também, segundo Cortina, "O pós-convencional, no qual distinguem os princípios universalistas das normas convencionais, 
de modo que julgar sobre o que é justo ou injusto, "colocando-se no lugar do outro" (2003, p.110), não é apenas uma questão de conhecimento, mas de formação. Não é só saber o que prescreve a norma, mas em circunstâncias, sobretudo diante de dilemas, ser capaz de medir o limite da norma.

Se tomarmos como pressuposto que as elaborações éticas, nas suas várias perspectivas, decorreram de conflitos e circunstância e que nenhuma responde satisfatoriamente a todas as situações, pode parecer que se está advogando um relativismo ou subjetivismo. Porém, se as elaborações éticas são resultado de impasses em dado contexto histórico, são também fruto de tentativas de transpor as orientações éticas existentes, na busca de melhor responder às situações do seu tempo.

Donaldson, por exemplo, lembra, em relação à concepção relativista, que: "A inadequação do relativismo cultural, contudo, tornou-se notória quando as práticas em questão são mais danosas do que pequenas propinas e negociações privilegiadas" (HARVARD BUSINESS REVIEW, 2005, p.23).

Discute assim, a questão ética empresarial em contextos e culturas diferentes, como por exemplo,

[...] em muitas culturas, a lealdade à comunidade, família, organização ou sociedade - é o fundamento de todo comportamento ético. Os japoneses, por exemplo, definem a ética de negócios em termos de lealdade à empresa, às redes de organizações e de relacionamentos e ao pais. Já os americanos valorizam mais a liberdade do que a lealdade; a tradição de direitos dos Estados Unidos enfatiza a igualdade, a eqüidade e a liberdade individual. (HARVARD BUSINESS REVIEW, 2005, p.23).

Donaldson defende, ainda, uma posição entre os extremos, entre o relativismo ético, de um lado - isto é, segundo o qual, nada é sagrado nada é errado - e, do outro lado, o que chama de absolutismo ético - segundo o qual deve-se adotar um mesmo comportamento, conduta em tempo e espaço. Para ele, a resposta situa-se entre esses dois

Educ. e Filos., Uberlândia, v. 20, n. 39, p. 219-251, jan./jun. 2006. 
extremos (2005. p.27). O relativismo falha, pois há valores, princípios fundamentais que transpõem as culturas. Algumas práticas são, inquestionavelmente, erradas, não importa onde. Em contrapartida, muitas coisas são apenas diferentes, mas não erradas.

Como orientação, Donaldson três princípios para os gestores, que são:

-Respeito pelos valores humanos essenciais, que determina o limiar moral absoluto para todas as atividades de negócios.

- Respeito pelas tradições locais.

- Crença em que o contexto é importante nas decisões sobre o que é certo e errado. (2005. p.29).

O agir ético é mais fácil quando os fatos e as alternativas são claros, mas quando há ambigüidade, dúvidas, situações em torno das quais há conflito de concepções, não é uma questão simples.

\section{Considerações finais}

O texto teve como objetivo discutir a gestão ética das organizações educacionais, com ênfase para a contribuição das várias teorias éticas, mediante três enfoques principais: deixar mais claro o que significa ética, e de que maneira, então, pode-se entender o que venha a ser ética na gestão das organizações, e que essa não significa tratar de costumes quaisquer. Para isso, procurou-se esclarecer as principais elaborações sobre as concepções éticas, sintetizando-as em três matrizes principais para que, também, ao se pretender implantar uma gestão ética, saibamos melhor as várias correntes com suas bases. Por último, discutiu-se como aproximar as teorias à prática da gestão, que relação pode se fazer entre as teorias éticas e a gestão ética, destacando que não é um caminho fácil, mas necessário.

Não se teve a pretensão de sugerir um programa ou modelo, até porque a implantação de um programa de ética não é fácil. Para isso, é preciso conhecer a organização, para identificar qual projeto pode ser mais adequado. 
Quer-se, para finalizar as considerações, levantar três questões importantes para uma gestão ética, ou para um gestor que busca desenvolver uma gestão ética, num contexto de múltiplas particularidades, que aparecem no dia-a-dia da atividade de um gestor, envolvendo autoridade, responsabilidade, autenticidade, transparência, veracidade, confiabilidade, entre outras.

Primeiro é preciso que se prime pelo desenvolvimento dos gestores como pessoas morais. Que se busque investimento para o alcance da competência ética do gestor, para que ele saiba fazer as leituras e adequar as ações a um nível ético. Nesse sentido, não é necessário que esse seja um gestor herói; às vezes, é melhor ser discreto, conforme descreve Badaracco Jr.:

Os líderes discretos prestam muita atenção aos limites do poder. Não superestimam sua própria influência sobre as pessoas ou a própria capacidade de controlar os eventos num mundo incerto. Os líderes discretos constatam que, na maioria das situações, ele ou ela é apenas uma peça num tabuleiro de xadrez. (HARVARD BUSINESS REVIEW, 2005, p. 21).

Nesse sentido, como sujeito, é importante que se tenha consciência dos valores morais fundamentais, entre eles: honestidade, justiça, veracidade, confiança, lealdade e outros.

Segundo, é importante haver consciência da influência da organização, com seu ambiente para a gestão ética. Todas as organizações formam uma determinada estrutura, que define as relações e os papéis no interior dela. $\mathrm{O}$ julgamento moral não pode ser atribuído a quem decide de forma isolada, sem um apoio participativo e sistemático. Naturalmente, isso depende do tamanho e da complexidade da organização.

Por fim, é necessário investir e implementar ações necessárias que levem para um caminho do desempenho ético. Nesse sentido, deve-se considerar a importância das condições institucionais, o padrão teórico que dará o norte, o que seja avaliado como certo e errado, bem ou mau, no âmbito organizacional e levar em conta 
que é preciso distinção entre o que são situações em que o agente sabe o que é certo fazer, mas deixa de fazê-lo, e as situações que são dilemas, em que o agente não sabe o que é certo fazer, e está diante de incerteza moral. Como já feito referência, na medida em que os valores organizacionais definem-se, são esclarecidos e praticados, diminuindo os dilemas para os gestores.

\section{Referências}

BIAGGIO, Angela Maria. Lawrence Kohlberg - Ética e educação moral. São Paulo: Moderna, 2002.

BRIEN, Jerry. Entrevista sobre Ethics Resource Center. Tradução: Andréia Kuno. Disponível im: www.eticaempresarial.com.br/ entrevistajessy.htm. Acessado em: 30/03/04.

CABANAS, José M.B. Pedagogia moral, el desarrollo moral integral. Madrid: Dykjnson, 1995.

CHAUÍ, Marilena. A universidade pública sob nova perspectiva. Conferência de abertura da $26^{a}$ Reunião Anual da Anped. Caxambú-MG.

COHEN, David. EXAME. Ed. 792, Ano 37, $N^{\circ} 10,14$ de maio de 2003, p.35-43.

CORTINA, Adela. O fazer ético - Guia para a educação moral. São Paulo: Moderna, 2003.

COSTA, Jorge Adelino. Imagens organizacionais da escola. Lisboa: Edições ASA, 1996.

DRUCKER, Peter. O melhor de Peter Drucker - a sociedade. São Paulo: Nobel, 2001.

ETZIONI, Amitai. Organizações modernas. São Paulo: Livraria Pioneira Editora, 1972. 
FREITAG, Bárbara. Itinerátios da Antigona - a questão da moralidade. 3. ed. Campinas/SP: Papirus, 2002.

GEISLER, Norman L. Ética cristã - alternativas e questões contemporâneas. São Paulo: Sociedade Religiosa Edições Vida Nova, 1972.

HARVARD BUSINESS REVIEW. Ética e responsabilidade social nas empresas. Tradutor Alfonso Celso da Cunha Serra. Rio de Janeiro: Elsevir, 2005.

HEGEDÜS, András. (Org.). In: OUTHWAITE, William e outros. Dicionário do pensamento social do século XX. Rio de Janeiro: Zahar Editor, 1996.

HOLMES, Arthur F. Ética - decisões à luz da Bíblia. Rio de Janeiro: Casa Publicadora Assembléia de Deus, 2002.

LEISINGER, Klaus M.; SCHMITT, Karin. Ética empresarial responsabilidade global e gerenciamento moderno. 2. ed. Petrópolis: ed. Vozes, 2001.

LIMA VAZ, Henrique C. de. Ética e direito. São Paulo: Ed. Loyola, 2002.

LIMA, Licinis C. A escola como organização educativa. São Paulo: Cortez, 2001.

MARCHIONNI, Antonio. A ética e seus fundamentos. In: Ética na virada do milênio. 2. ed. São Paulo: LTr, 1999.

MARQUES, Ramiro. O livro das virtudes de sempre. Porto: Landy, 2001.

MINISTÉRIO DA EDUCAÇÃO. Reforma universitária - cinco razões. Disponível in: www.mec.gov.br/reforma. Acessado em: $28 / 11 / 2004$.

Educ. e Filos., Uberlândia, v. 20, n. 39, p. 219-251, jan./jun. 2006. 
MORAIS, João. Epicuro - as luzes da ética. São Paulo: Editora Moderna, 1998.

OLIVEIRA, Manfredo. A de. (Org.). Correntes fundamentais da ética contemporânea. 2. ed. Petrópolis: Ed. Vozes, 2000.

PGORARO, Olinto A . Ética e justiça. 7. ed. Petrópolis: Ed. Vozes, 1995.

RIOS, Terezinha A. Compreender e ensinar - por uma docência da melhor qualidade. São Paulo: Cortez Editora, 2001.

SROUR, Robert Henry. Ética empresarial - a gestão da reputação. 2. ed. Rio de Janeiro: Campus, 2003.

SROUR, Robert Henry. Poder, cultura e ética nas organizações. $4^{\mathrm{a}} \mathrm{ed}$. Rio de Janeiro: Campus, 1998.

SÁ, Antonio Lopes de. Ética profissional. São Paulo: Ed. Atlas S.A., 2001. Reunião Anual da ANPEd. Poços de Caldas: 05 de outubro de 2003, p.1-12.

TUGENDHAT, Ernst. Lições de ética. Petrópolis: Ed. Vozes, 1997.

TAMAYO, Alvaro.; BORGES-ANDRADE, Jairo Eduardo; CABO, Wanderley (Org.). Trabalho; organizações e cultura. São Paulo: ANPEPP, s/d.

VAZQUEZ, Adolfo Sanchez. Ética. 5. ed. Rio de Janeiro: Civilização Brasileira, 1982. 